\title{
The Effect of Body Mass Index on the Mortality of Patients Followed up in the Intensive Care Unit with COVID-19 Diagnosis
}

\author{
Yoğun Bakım Ünitesinde COVID-19 Tanısı ile Takip Edilen Hastalarda Beden \\ Kitle İndeksinin Mortaliteye Etkisi
}

\author{
Duygu Akyol ${ }^{1}$, (D) Rabia Yılmaz², (D) Nalan Saygı Emir ${ }^{3}$ \\ ${ }^{1}$ University of Health Sciences Turkey, Başakşehir Çam and Sakura City Hospital, Clinic of Anesthesiology and Reanimation, Istanbul, Turkey \\ ${ }^{2}$ University of Health Sciences Turkey, Bakırköy Dr. Sadi Konuk Training and Research Hospital, Clinic of Critical Care Medicine, Istanbul, Turkey \\ 3 University of Health Sciences Turkey, Bakırköy Dr. Sadi Konuk Training and Research Hospital, Clinic of Anesthesiology and Reanimation, \\ Istanbul, Turkey
}

\begin{abstract}
Objective: The Coronavirus disease-2019 (COVID-19) pandemic continues its effect worldwide. Studies that examine the relationship between the body mass index (BMI) and COVID-19 have reported inconsistent results. Thus, this study aimed to investigate the effect of BMI on severe COVID-19 and mortality to resolve this uncertainty between BMI and COVID-19.

Methods: This study was designed as a retrospective cohort study and was conducted by analyzing data from 219 patients with a diagnosis of COVID-19 who were followed up at University of Health Sciences Turkey, Bakırköy Dr. Sadi Konuk Training and Research Hospital Training and Research Hospital between March 15, 2021, and August 15, 2021.

Results: Patients were divided into two groups as obese $(n=53 ; 24.2 \%)$ and nonobese $(n=166 ; 75.8 \%)$ patients. Males were more prevalent in the obese group, whereas females were more prevalent in the nonobese group. The incidence of diabetes mellitus and chronic obstructive pulmonary disease (COPD) was found higher in patients with obesity than those without obesity $(p<0.005)$. Disease severity scores calculated after the intensive care unit (ICU) admission were similar in both groups. The incidence of arterial and central venous catheters was found to be higher in patients with obesity $(p<0.05)$. The incidence of acute kidney injury was found to be more prevalent in patients with obesity $(p<0.05)$. The Ppeak was higher in patients with obesity in the mechanical ventilator parameters; however, their tidal volume was found to be lower $(p<0.05)$. Mechanical ventilation time and ICU stay were observed to be higher in patients with obesity $(p<0.05)$. Mortality rates were similar in patient with obesity $(n=83 ; 50 \%)$ and without $(n=27 ; 50.9 \%)$.
\end{abstract}

Conclusion: Our research results revealed similar ICU scores and laboratory values; however, patients with obesity had longer ICU stay and mechanical ventilation periods. Further, no relationship was found between BMI and mortality.

Keywords: COVID-19, Coronavirus, obesity, body mass index, critical care, mortality

\section{öz}

Amaç: Koronavirüs hastalığı-2019 (COVID-19) pandemisi tüm dünyayı etkilemeye devam etmektedir. Beden kitle indeksi (BKI) ve COVID-19 ilişkisini araştıran çalışmalar, BKi ve COVID-19 arasındaki ilişki hakkında tutarsız sonuçlar bildirmiştir. Bu araştırma BKi ve COVID-19 arasındaki bu belirsizliği gidermek amacıyla BKI'nin şiddetli COVID-19 ve mortalite üzerine etkisini belirlemek amacıyla planlandı.

Gereç ve Yöntem: Retrospektif kohort olarak planlanan bu araştırma 15 Mart 2021-15 Ağustos 2021 tarihleri arasında Sağlık Bilimleri Üniversitesi, Bakırköy Dr. Sadi Konuk Eğitim ve Araştırma Hastanesi'nde takip edilen COVID-19 tanılı 219 hastanın verileri analiz edilerek gerçekleştirildi.

Results: Hastalar obez $(53 ; \% 24,2)$ ve non-obez $(166 ; \% 75,8)$ hastalar olmak üzere iki gruba ayrıldı. Obez hastalarda erkek, non-obez hastalarda kadın cinsiyet daha sık görüldü. Obez hastalarda diabetes mellitus ve kronik obstrüktif akciğer hastalığı görülme sıklığının, non-obez hastalardan daha yüksek olduğu saptandı $(p<0,005)$. Yoğun bakım ünitesi (YBÜ) kabulü sonrası hesaplanan hastalık şiddeti skorları her iki grupta benzer

Address for Correspondence: Duygu Akyol, University of Health Sciences Turkey, Başakşehir Çam and Sakura City Hospital,

Clinic of Anesthesiology and Reanimation, Istanbul, Turkey

Phone: +90 5447616034 E-mail: dr.duyguaygun@gmail.com ORCID ID: orcid.org/0000-0001-7956-9942

Cite as: Akyol D, Yılmaz R, Saygı Emir N. The Effect of Body Mass Index on the Mortality of Patients Followed up in the Intensive Care Unit with COVID-19 Diagnosis. Med J Bakirkoy 2021;17:392-399

Received: 20.10 .2021

Accepted: 15.11 .2021 
bulundu. Arter kateteri ve santral venöz kateter uygulanma sıklığı obez hastalarda daha yüksek bulundu $(p<0,05)$. Obez hastalarda akut böbrek hasarı gelişme sıklığının arttığı saptandı $(p<0,05)$. Mekanik ventilatör parametrelerinde obez hastalarda Ppeak daha yüksek olmasına rağmen tidal volum daha düşük bulundu $(p<0,05)$. Mekanik ventilasyon süresi ve YBÜ kalış süresi obez hastalarda daha yüksek bulundu ( $p<0,05)$. Mortalite oranları obez $(83 ; \% 50)$ ve non-obez $(27 ; \% 50,9)$ hastalarda benzerdi.

Sonuç: Araştırmamız sonucunda YBÜ skorları ve laboratuar değerleri benzer olmasına rağmen obez hastaların YBÜ yatış süresi ve mekanik ventilasyon süresinin daha uzun olduğu belirlendi. Ancak, BKi ve mortalite arasında ilişki bulunamadı.

Anahtar Kelimeler: COVID-19, Koronavirüs, obezite, beden kitle indeksi, yoğun bakım, mortalite

\section{INTRODUCTION}

On March 11, 2020, the World Health Organization proclaimed the Coronavirus disease-2019 (COVID-19) as a pandemic, which piqued public interest in an infectious disease rife with unknowns (1). The COVID-19 pandemic has inspired global research attempts to identify those who are most likely to suffer severe illness and die (2). Diabetes mellitus (DM), lung disorders, cardiovascular disease, and renal disease are all linked to an elevated risk of negative outcomes in COVID-19 individuals according to preliminary studies (3-5). Additionally, some studies have linked increased body mass index (BMI) and obesity with more severe COVID-19 and increased mortality (6-9).

Obesity is considered an important public health problem. DM was shown to be associated with cardiovascular disease, respiratory tract diseases, some types of cancer, and increased morbidity and mortality due to any cause (1012). However, epidemiological studies and meta-analyses investigating the relationship between BMI and COVID-19 have reported inconsistent results about. While some studies suggest that increased BMI and obesity worsen the disease outcome $(9,13,14)$, others suggest no effect on disease outcomes $(15,16)$. Obesity is uncertain to be a risk factor for COVID-19 because of the disparities in the current research results. The relationship between the BMI and COVID-19 severity and risk of mortality is unclear.

Thus, this research aimed to investigate the effect of BMI on the severe COVID-19 and mortality to resolve this uncertainty between BMI and COVID-19.

\section{METHODS}

\section{Data-center}

The presented retrospective study was performed after the approval of the local ethics committee (number: 2021/413). This study was designed as a retrospective cohort and was conducted in the University of Health Sciences Turkey, Bakırköy Dr. Sadi Konuk Training and Research Hospital with 27 intensive care unit (ICU) level-3 beds in Istanbul, Turkey. Written informed consent was obtained from the patients and their relatives.
This center admits an average of 1,760 patients in the medical-surgical ICU annually. This closed unit provides intensive care services on a 24/7 basis in which extracorporeal treatments are performed by intensive care specialists, with a nurse-patient ratio of 1:2.

After removing the clothes of all patients who are admitted to the ICU, their height and weight are measured by the staff and recorded in the clinical decision support system. During this measurement, treatments such as intravenous fluids and diuretics are administered to the patient before the ICU admission. After entering the weight and height data, the BMI is calculated and automatically saved by the system. Thus, the patient's BMI value is quickly and precisely recorded.

\section{Data Collection}

The data of patients who were followed up between March 15, 2021, and August 15, 2021, were obtained using the Structured Query Language queries from the EMRall-Qlinl CUlmd Soft Metavision Clinical Decision Support System used in the ICU and were retrospectively analyzed. During the research period, all patients diagnosed with COVID-19 and admitted to the ICU were treated according to the Ministry of Health's published and revised recommendations (17). Demographic characteristics of patients, BMI values, length of stay, developing AMI warnings, disease severity scores calculated in the ICU, mean potential hydrogen $(\mathrm{pH})$, partial pressure of oxygen $\left(\mathrm{PO}_{2}\right)$, and partial pressure of carbon dioxide $\left(\mathrm{PCO}_{2}\right)$ obtained from the blood gas samples taken in the ICU, lactate values, treatments (vasoactive drugs and antibiotics) and interventions applied in the ICU, mechanical ventilation parameters, such as respiratory rate per minute, positive end-expiratory pressure, the fraction of inspired oxygen, work of breathing ventilator, Tidal volume and $\mathrm{P}$ peak data, mechanical ventilation time, and mortality data were analyzed.

\section{Sample}

We aimed to sample all patients admitted to the ICU with the diagnosis of COVID-19 at the time of the research. During the research period, 28,260 outpatients were admitted to our hospital with a pre-diagnosis of COVID-19. A total of 
1,870 patients with a confirmed diagnosis of COVID-19 were hospitalized. The ICU received 275 patients who had been diagnosed with COVID-19. After applying the exclusion criteria, 219 patients followed up in the ICU were included in the study.

\section{Sample Criteria}

All patients with COVID-19 over the age of 18 years, who were followed in the ICU for more than $24 \mathrm{~h}$, were planned to be included in the study.

\section{Exclusion Criteria}

Patients younger than 18 years $(n=1)$,

Patients admitted to the service within the first $24 \mathrm{~h}$ in the ICU ( $n=2)$,

Patients who developed mortality in the first $24 \mathrm{~h}$ in the ICU $(n=22)$,

Patients with missing data $(n=31)$.

\section{Primary Result}

Examining the effect of BMI on mortality in patients with COVID-19 was determined as the primary aim of the study.

\section{Secondary Results}

Patients' comorbidities, admission diagnoses, scores computed after admission to ICU, laboratory results, interventions and therapies, mechanical ventilator data, acute kidney injury (AKI) progression and stages, and ICU mortality were compared according to BMI categories as secondary goals of the study.

\section{Statistical Analysis}

The data collected in the study were analyzed using the Statistical Package for the Social Sciences 22.00 program. Categorical variables were presented as frequency ( $n$ ) and percentage (\%), numerical variables as mean and standard deviation, or median and interquartile ranges. The independent sample t-test and Mann-Whitney $U$ test were used to compare numerical data. The Chi-square test and Fisher Exact test were utilized for categorical variables. Receiver-operating characteristic (ROC) analysis was used to examine the effect of BMI on ICU mortality and to determine the cut-off value to predict mortality. The statistical significance level was accepted as a p-value of $<0.05$.

\section{Findings}

A total of 219 patients who are admitted to the ICU during the study period were divided into two groups as patients with obesity $(n=53 ; 24.2 \%)$ and those without obesity $(n=166$;
75.8\%). Demographic characteristics and comorbidities of patients are given in Table 1. Males were more prevalent in the obese group, whereas females were more prevalent in the nonobese group. Patients with obesity were younger than those without obesity $(p<0.05)$. Comorbid disease frequency and Charlson comorbidity index score were similar between the groups. Hypertension was found to be the most common comorbidity in both groups. The other comorbid diseases examination found that the incidence of DM and COPD in patients with obesity was higher than those without obesity $(p<0.005)$. The frequency of other comorbid diseases was similar among the groups.

Table 1. Demographic characteristics and comorbidities of patients

\begin{tabular}{|c|c|c|c|}
\hline Parameters & $\begin{array}{l}\text { Non-obese } \\
(n=166 ; 75.8 \%)\end{array}$ & $\begin{array}{l}\text { Obese } \\
(n=53 ; 24.2 \%)\end{array}$ & $p$ \\
\hline BMI, median (IQR) & $26.0(23.9-27.8)$ & $33.1(31.1-38.6)$ & - \\
\hline $\begin{array}{l}\text { Age, year (mean } \\
\pm \text { SD) }\end{array}$ & $64(50-73)$ & $55(48-69)$ & 0.040 \\
\hline$<50$ & $39(23.5)$ & $15(28.3)$ & 0.480 \\
\hline $50-59$ & $31(18.7)$ & $17(32.1)$ & 0.040 \\
\hline $60-69$ & $41(24.7)$ & $8(15.1)$ & 0.144 \\
\hline $70-79$ & $31(18.7)$ & $10(18.9)$ & 0.975 \\
\hline$\geq 80$ & $24(14.5)$ & $3(5.7)$ & 0.090 \\
\hline Gender & - & - & 0.005 \\
\hline Male & $114(68.7)$ & $25(47.2)$ & - \\
\hline Female & $52(31.3)$ & $28(52.8)$ & - \\
\hline $\mathrm{CCl}$, median (IQR) & $3(1-6)$ & $3(1-5)$ & 0.104 \\
\hline Comorbidity & $125(75.3)$ & $38(71.7)$ & 0.601 \\
\hline $\mathrm{HT}$ & $65(39.2)$ & $23(43.4)$ & 0.584 \\
\hline Diabetes mellitus & $44(26.5)$ & $22(41.5)$ & 0.038 \\
\hline CAD & $31(18.7)$ & $10(18.9)$ & 0.975 \\
\hline $\mathrm{CHF}$ & $18(10.8)$ & $6(11.3)$ & 0.923 \\
\hline SVD & $16(9.6)$ & $1(1.9)$ & $0.051^{*}$ \\
\hline Demans & $6(3.6)$ & $1(1.9)$ & $0.462^{\star}$ \\
\hline COPD & $16(9.6)$ & $13(24.5)$ & 0.005 \\
\hline Liver disease & $7(4.2)$ & $1(1.9)$ & $0.383^{*}$ \\
\hline CKD & $18(10.8)$ & $5(9.4)$ & 0.771 \\
\hline Malignancy & $20(12.0)$ & $5(9.4)$ & 0.602 \\
\hline Other & $16(9.6)$ & $4(7.5)$ & $0.442^{\star}$ \\
\hline
\end{tabular}

*Unless otherwise stated, results are n; given as \%. BMI: Body mass index, $\mathrm{CCl}$ : Charlson comorbidity index, HT: Hypertension, CAD: Coronary artery disease, CHF: Congestive heart failure, IQR: Interquartile range, SVD: Cerebrovascular disease, COPD: Chronic obstructive pulmonary disease, CKD: Chronic kidney disease 
Initial Acute Physiology and Chronic Health Evaluation (APACHE) II, APACHE IV, Simplified Acute Physiology Score III, and Sequential Organ Failure Assessment scores calculated after the ICU admission were similar in both groups. Considering the interventions performed in the $I C U$, the frequency of arterial and central venous catheters were found to be higher in patients with obesity $(p<0.05)$. The frequency of hemodialysis, mechanical ventilation, and tracheostomy was similar in both groups. The frequency of treatments performed on both groups was similar. Complications that developed included the incidence of AKI that was higher in patients with obesity, and the rate of secondary infection was similar between the groups. Mechanical ventilation time and ICU stay were found to be higher in patients with obesity (Table 2). Mortality rates were similar in patients with obesity $(n=83 ; 50 \%)$ and those without ( $n=27 ; 50.9 \%)$. The $R O C$ analysis results that were performed to investigate the relationship between the BMI and mortality and determine a BMI value to predict mortality between the groups found no relationship between the BMI and mortality (AUC: 0.499) (Figure 1).

The laboratory parameter examined of patients with obesity and without obesity revealed that the laboratory parameters and blood gas values of patients were similar during

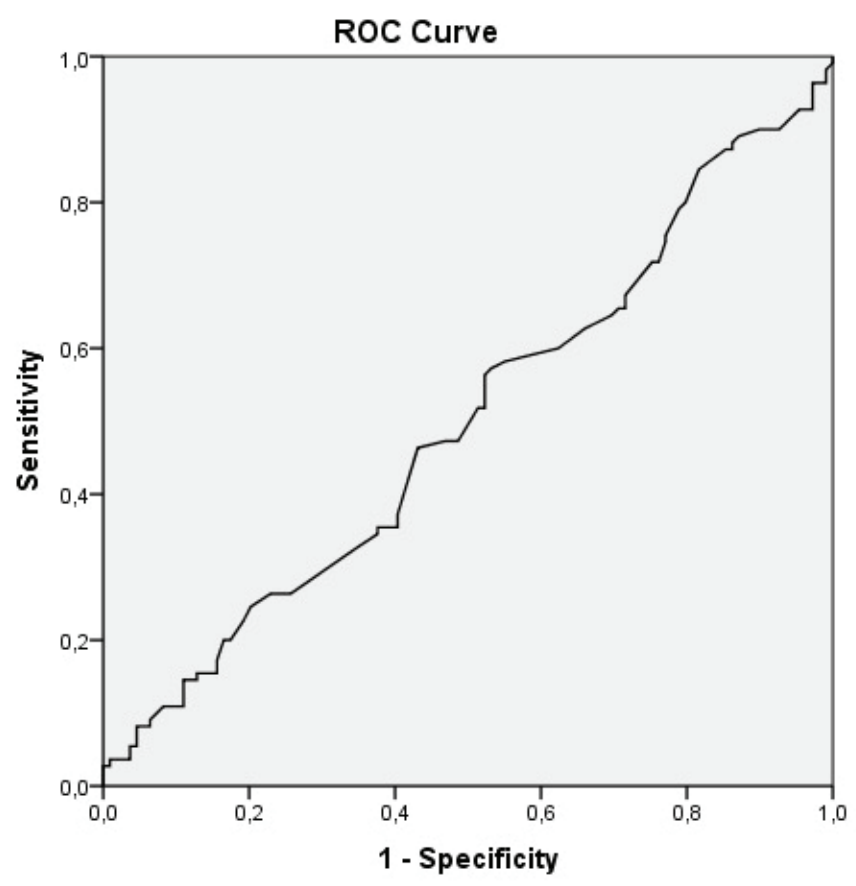

Diagonal segments are produced by ties.

Figure 1. ROC analysis results for $\mathrm{BMI}$ and motility relationship (AUC: 0.499)

BMI: Body mass index, AUC: Area under curve, ROC: Receiver operating characteristic admission. Ppeak was observed to be higher in patients with obesity in the mechanical ventilator parameters; however, their tidal volume was found to be lower $(p<0.05)$. No difference was found in other mechanical ventilator parameters (Table 3).

Table 2. Intensive care scores of patient interventions and treatments

\begin{tabular}{llll} 
Parameters & $\begin{array}{l}\text { Non-obese } \\
(\mathbf{n}=166 ; 75.8 \%)\end{array}$ & $\begin{array}{l}\text { Obese } \\
(\mathrm{n}=53 ; \mathbf{2 4 . 2} \%)\end{array}$ & $\mathrm{p}$ \\
\hline $\begin{array}{l}\text { APACHE II, median } \\
\text { (IQR) }\end{array}$ & $22(16-28)$ & $21(17-26)$ & 0.530 \\
\hline $\begin{array}{l}\text { APACHE IV, median } \\
\text { (IQR) }\end{array}$ & $64(38-95)$ & $63(37-84)$ & 0.659 \\
\hline $\begin{array}{l}\text { SAPS III, median } \\
\text { (IQR) }\end{array}$ & $56(42-72)$ & $58(50-69)$ & 0.708 \\
\hline $\begin{array}{l}\text { SOFA, median } \\
\text { (IQR) }\end{array}$ & $6(2-9)$ & $6(3-11)$ & 0.408 \\
\hline
\end{tabular}

Initiatives

\begin{tabular}{lccc}
\hline Arterial catheter & $147(88.6)$ & $52(98.1)$ & 0.035 \\
\hline $\begin{array}{l}\text { Central venous } \\
\text { catheter }\end{array}$ & $130(78.3)$ & $48(90.6)$ & 0.046 \\
\hline Hemodialysis & $45(27.1)$ & $15(28.3)$ & 0.865 \\
\hline $\begin{array}{l}\text { Mechanical } \\
\text { ventilation }\end{array}$ & $128(77.1)$ & $46(86.8)$ & 0.129 \\
\hline $\begin{array}{l}\text { Tracheostomy } \\
\text { Treatment }\end{array}$ & $23(13.9)$ & $7(13.2)$ & 0.905 \\
\hline
\end{tabular}

\begin{tabular}{|c|c|c|c|}
\hline Hydroxychloroquine & $83(50.0)$ & $29(54.7)$ & 0.550 \\
\hline Favipiravir & $118(71.1)$ & $41(77.4)$ & 0.373 \\
\hline Ritonavir/lopinavir & $17(10.2)$ & $7(13.2)$ & 0.547 \\
\hline Tocilizumab & 31 (18.7) & $9(17.0)$ & 0.781 \\
\hline Steroid & 38 (22.9) & $12(22.6)$ & 0.970 \\
\hline Vasoactive agent & $130(78.3)$ & $41(77.4)$ & 0.884 \\
\hline Antibiotic & $154(92.8)$ & $50(94.3)$ & 0.487 \\
\hline Blood product & $72(43.4)$ & $26(49.1)$ & 0.469 \\
\hline Secondary infection & $84(50.6)$ & $26(49.1)$ & 0.845 \\
\hline AKI & 107 (64.5) & $42(79.2)$ & 0.044 \\
\hline $\begin{array}{l}\text { Mechanical } \\
\text { ventilation time, } \\
\text { median (IQR) }\end{array}$ & $5.6(1.8-11.6)$ & $10.3(3.4-14.9)$ & 0.017 \\
\hline $\begin{array}{l}\text { ICU length of stay, } \\
\text { median (IQR) }\end{array}$ & $6.3(2.6-14.8)$ & $11.3(6.0-17.3)$ & 0.004 \\
\hline Mortality & $83(50.0)$ & 27 (50.9) & 0.905 \\
\hline \multicolumn{4}{|c|}{$\begin{array}{l}\text { *Unless otherwise stated, results are n; given as \%. APACHE II: Acute } \\
\text { physiology and chronic health assessment II, APACHE IV: Acute physiology } \\
\text { and chronic health assessment iv, SAPS III: Simplified acute physiology score } \\
\text { III, SOFA: Sepsis-related organ failure assessment, AKI: Acute kidney injury, } \\
\text { ICU: Intensive care unit, IQR: Interquartile range }\end{array}$} \\
\hline
\end{tabular}




\section{RESULT}

Study results in the examination of the relationship between the $\mathrm{BMI}$ and mortality in patients who are followed up with the diagnosis of COVID-19 in the ICU found no relationship.

Table 3. Laboratory and clinical parameters of patients

\begin{tabular}{|c|c|c|c|}
\hline Parameters & $\begin{array}{l}\text { Non-obese } \\
(n=166 ; 75.8 \%)\end{array}$ & $\begin{array}{l}\text { Obese } \\
(n=53 ; 24.2 \%)\end{array}$ & $p$ \\
\hline $\begin{array}{l}\text { Lymphocyte } \\
\text { count }\end{array}$ & $0.75(0.46-1.25)$ & $0.67(0.41-1.12)$ & 0.305 \\
\hline Ferritin & $529(217-1164)$ & $511(178-1101)$ & 0.817 \\
\hline Procalcitonin & $0.94(0.25-4.80)$ & $0.64(0.21-1.66)$ & 0.218 \\
\hline CRP & $152(63-237)$ & $145(54-216)$ & 0.438 \\
\hline Troponin & $72(17-245)$ & $56(14-167)$ & 0.792 \\
\hline D-Dimer & $1.85(0.83-4.95)$ & $1.89(0.63-4.77)$ & 0.365 \\
\hline $\begin{array}{l}\text { Fibrinogen, } \\
\text { (mean } \pm \text { SD) }\end{array}$ & $488 \pm 176$ & $521 \pm 175$ & 0.237 \\
\hline $\begin{array}{l}\mathrm{pH},(\text { mean } \pm \\
\mathrm{SD})\end{array}$ & $7.28 \pm 0.16$ & $7.32 \pm 0.12$ & 0.136 \\
\hline $\mathrm{pO}_{2}$ & $65(48-84)$ & $65(44-76)$ & 0.343 \\
\hline $\mathrm{pCO}_{2}$ & $38.1(30.7-48.2)$ & $36.8(30.1-48.1)$ & 0.841 \\
\hline Lactate & $1.5(1.1-1.9)$ & $1.1(1.0-1.9)$ & 0.167 \\
\hline Glucose & $156(121-212)$ & $153(116-206)$ & 0.654 \\
\hline ALT & $29(17-65)$ & $30(18-57)$ & 0.947 \\
\hline AST & $49(29-89)$ & $63(25-125)$ & 0.437 \\
\hline Sodium & $137(134-142)$ & $137(133-141)$ & 0.567 \\
\hline $\begin{array}{l}\text { Hemoglobin, } \\
\text { (mean } \pm \text { SD) }\end{array}$ & $10.8 \pm 2.5$ & $10.5 \pm 2.0$ & 0.337 \\
\hline $\begin{array}{l}\text { Hematocrit, } \\
\text { (mean } \pm \text { SD) }\end{array}$ & $33.5 \pm 7.4$ & $32.4 \pm 5.5$ & 0.309 \\
\hline PLT & $216(150-298)$ & $225(171-297)$ & 0.432 \\
\hline WBC & $10.98(7.86-16.35)$ & $11.56(7.38-16.53)$ & 0.974 \\
\hline $\begin{array}{l}\text { Respiratory } \\
\text { Rate }\end{array}$ & $25(20-34)$ & $27(21-35)$ & 0.272 \\
\hline $\begin{array}{l}\text { Fever (mean } \\
\pm \mathrm{SD} \text { ) }\end{array}$ & $36.9 \pm 1.1$ & $36.9 \pm 1.4$ & 0.890 \\
\hline $\mathrm{PaO}_{2} / \mathrm{FiO}_{2}$ & $144(93-206)$ & $112(85-215)$ & 0.433 \\
\hline $\mathrm{FiO}_{2}$ & $60(45-76)$ & $50(41-70)$ & 0.359 \\
\hline PEEP & $8(7-9)$ & $9(7-10)$ & 0.431 \\
\hline TV & 507 (413-579) & 445 (409-514) & 0.029 \\
\hline Ppeak & $20(17-25)$ & $25(23-27)$ & 0.048 \\
\hline WOBv & $1.32(1.19-1.54)$ & $1.37(1.09-1.58)$ & 0.831 \\
\hline
\end{tabular}

*Unless otherwise stated, results are $n$; given as \%. CRP: C-reactive protein, $\mathrm{pO}_{2}$ : Partial oxygen pressure, $\mathrm{pCO}_{2}$ : Partial carbon dioxide pressure, ALT: Alanine Aminotransferase, AST: Aspartate aminotransferase, PLT: Platelet, WBC: White blood cell, $\mathrm{PaO}_{2}$ : Partial arterial oxygen pressure, $\mathrm{FiO}_{2}$ : Inspired fraction of oxygen exhaled, PEEP: Positive end-expiratory pressure, TV: Tidal volume, Ppeak: Inspiratory peak airway pressure, Pplato: Plateau pressure, WOBv: Work of breathing ventilator, SD: Standard deviation

\section{DISCUSSION}

Our research results revealed similar ICU scores and laboratory values; however, patients with obesity were concluded to have longer ICU stay and mechanical ventilation periods. In addition, patients with obesity were younger; however, their frequency of DM and COPD and incidence of AKI were higher.

Obesity is a common problem today and the number of obese individuals is expected to increase further in the coming years $(18,19)$. Increased obesity was previously revealed in many comorbid diseases, including cardiovascular diseases and DM (20). Our research results show that our patients with obesity and COVID-19 are younger; however, their frequency of DM and COPD is higher. Our findings are compatible with the results in the literature. Previous studies on patients with COVID-19 revealed an increased BMI and the association of COPD and DM were common, which increase with the severity of the disease (21-23). The severity and mortality of COVID-19 were found to be associated with age, gender, and comorbidities, such as cardiovascular diseases and respiratory diseases, in similar studies (23-26). Individuals with comorbid diseases were observed to often have overexpression of the angiotensin-converting enzyme-2 (ACE-2) receptor (27). Severe Acute Respiratory syndromeCoronavirus-2 (SARS-CoV-2) infects the respiratory system, as well as other organs and systems in humans via attaching to the ACE-2 receptor in human cells after spike protein activation by transmembrane protease serine 2 . This may explain the COVID-19 susceptibility of patients with obesity and comorbidities. Obesity and chronic inflammation are closely associated with proinflammatory activation and resulting endothelial dysfunction. Chronic inflammation in patients with obesity was estimated to contribute to the higher mortality due to increased inflammatory response to COVID-19 infection and impaired T-cell-induced immune response (28), which is characterized by obesity, adipose tissue remodeling, and proinflammatory changes in the adipokine profile $(29,30)$. Obesity has been linked to an imbalance of pro- and anti-inflammatory adipokines, which has been linked to an increased risk of acute lung damage (30).

Our research results revealed that although the peak pressure was higher in patients with obesity who received mechanical ventilation support, they had lower tidal volumes. This situation can be explained by the effects of the increased adipose tissue on respiratory physiology. Patients with obesity have increased adipose tissue in the thoracic and abdominal walls that exerts extra pressure on the chest wall and diaphragm. Therefore, the diaphragm is 
displaced toward the thorax and the lung volumes decrease (31). Patients with obesity are ventilated at higher pressures $(32,33)$ during mechanical ventilation; however, they tend to have lower lung volume and functional residual capacity (34). In addition, due to venous stasis and reduced arterial perfusion, patients with obesity in the ICU are at risk for increased intra-abdominal pressure $(35,36)$. Moreover, increased visceral fat accumulation in the abdominal area may increase the intra-abdominal pressure and cause an increased respiratory workload $(32,33)$. Finally, obesity is a known risk factor for the development of acute respiratory distress syndrome $(37,38)$.

Our research result found a longer duration of ICU stays in patients with obesity than those without obesity. Patients with obesity were previously seen with a longer ICU stay (39). Studies on patients with COVID-19 found that patients with obesity and COVID-19 have a longer hospitalization period, similar to our results $(40,41)$ since patients with obesity are more susceptible to complications. Vascular problems are common in patients with obesity, and our study found a higher frequency of using arterial catheters and central venous catheters in these patients. This may lead to infection and catheter-related complications, thus prolonging the duration of the ICU stay. In addition, the incidence of pressure ulcers increases in patients with obesity due to the deterioration of tissue perfusion due to the increased adipose tissue (42). Our investigation found no difference in ICU mortality across the groups. No statistically detectable phenomena were found that linked fat individuals to higher ICU survival $(42,43)$. Obesity is an independent risk factor for the development of AKI, which leads to prolonged ICU stay and increased mortality (44-46). Finally, nursing care becomes difficult in patients with obesity due to the large body surface area. This may lengthen the ICU follow-up period by increasing complications such as skin laceration and infection (47).

Our investigation found no difference in ICU mortality across the groups. The phenomenon that associated obese patients with better survival in the ICU could not be statistically detected. In the ROC analysis carried out to find a cut-off value for which BMI could be associated with mortality, no significant results could be obtained. Obesity is a risk factor for morbidity and death owing to SARS-CoV-2 infection, regardless of its connection with other comorbidities, according to previous research $(48,49)$. Some studies have suggested that it has no effect on patient outcomes, which is consistent with our results (50). This may be related to the younger age of patients with obesity. In addition, the presence of patients with multiple types of obesity in the ICU and the differences in patients with obesity may affect the results. Patients with obesity vary according to obesity classes and comorbid disease burdens. Given these previous findings in patients with obesity and COVID-19, patients with and without obesity in our critically ill cohort had similar disease severity and mortality. Obesity appears to be a risk factor for serious disease in COVID-19; however, our findings show that individuals with obesity, who become critically sick, have inflammatory profiles comparable to those who are not.

\section{Study Limitations}

In addition to the strengths of our research, such as preventing data loss using an electronic query of the clinical decision support system and completing all treatment processes of the patients in our center, our research also has some limitations. First, the retrospective study design may pose a risk of bias that may affect the results. Having a single-centered population prevents the generalization of results. Patients with obesity were younger than those without obesity in our sample has the potential to affect the results. The lack of other data to support obesity defined by BMI, such as waist circumference and waist-hip ratio, may have influenced the accuracy of the groups created using BMI. Insufficient records of administered diuretic or fluid therapy before the ICU admission may have affected the $\mathrm{BMI}$ and $\mathrm{AMI}$ data by changing the weight and urine amount of patients that was measured in the ICU.

\section{CONCLUSION}

Patients with obesity followed up in the ICU with COVID-19 diagnosis have longer periods of ICU stay and mechanical ventilation. In addition, patients with obesity are younger and their frequency of DM and COPD is also higher. The incidence of AKI increases in patients with obesity. However, no association was found between obesity and mortality.

\section{ETHICS}

Ethics Committee Approval: The study were approved by the University of Health Sciences Turkey, Bakırköy Dr. Sadi Konuk Training and Research Hospital of Local Ethics Committee (number: 2021/413).

Informed Consent: Written informed consent was obtained from the patients and their relatives.

\section{Authorship Contributions}

Surgical and Medical Practices: D.A., R.Y., N.S.E., Concept: D.A., R.Y., N.S.E., Design: D.A., R.Y., N.S.E., Data Collection or Processing: D.A., N.S.E., Analysis or Interpretation: D.A., Literature Search: D.A., R.Y., N.S.E., Writing: D.A., R.Y., N.S.E. 
Conflict of Interest: No conflict of interest was declared by the authors.

Financial Disclosure: The authors declared that this study received no financial support.

\section{REFERENCES}

1. World Health Organization. WHO Director-General's opening remarks at the media briefing on COVID-19-11 March 2020. Geneva, Switzerland: World Health Organization; 2020. https://www.who. $\mathrm{int} / \mathrm{dg} / \mathrm{speeches/detail/who-director-general-s-opening-remarks-}$ at-the-media-briefing-on-covid-19---11-march-2020

2. Hui DS, I Azhar E, Madani TA, Ntoumi F, Kock R, Dar O, et al. The continuing 2019-nCoV epidemic threat of novel coronaviruses to global health - The latest 2019 novel coronavirus outbreak in Wuhan, China. Int J Infect Dis 2020;91:264-6.

3. Li M, Dong Y, Wang H, Guo W, Hu D, Guo W, et al. Cardiovascular disease potentially contributes to the progression and poor prognosis of covid-19. Nutr Metab Cardiovasc Dis 2020;30:1061-7.

4. Aggarwal G, Cheruiyot I, Aggarwal S, Wong J, Lippi G, Lavie CJ, et al. Association of Cardiovascular Disease With Coronavirus Disease 2019 (COVID-19) Severity: A Meta-Analysis. Curr Probl Cardiol 2020;45:100617.

5. Mantovani A, Byrne CD, Zheng MH, Targher G. Diabetes as a risk factor for greater COVID-19 severity and in-hospital death: A meta-analysis of observational studies. Nutr Metab Cardiovasc Dis 2020;30:1236-8.

6. Ekiz T, Pazarlı AC. Relationship between COVID-19 and obesity. Diabetes Metab Syndr 2020;14:761-3.

7. Hussain A, Vasas P, El-Hasani S. Letter to the Editor: Obesity as a risk factor for greater severity of COVID-19 in patients with metabolic associated fatty liver disease. Metabolism 2020;108:154256.

8. Yates T, Razieh C, Zaccardi F, Rowlands AV, Seidu S, Davies MJ, et al. Obesity, walking pace and risk of severe COVID-19 and mortality: analysis of UK Biobank. Int J Obes (Lond) 2021;45:1155-9.

9. Palaiodimos L, Kokkinidis DG, Li W, Karamanis D, Ognibene J, Arora $\mathrm{S}$, et al. Severe obesity, increasing age and male sex are independently associated with worse in-hospital outcomes, and higher in-hospital mortality, in a cohort of patients with COVID-19 in the Bronx, New York. Metabolism 2020;108:154262.

10. Flegal KM, Carroll MD, Ogden CL, Johnson CL. Prevalence and trends in obesity among US adults, 1999-2000. JAMA 2002;288:1723-7.

11. Marik P, Varon J. The obese patient in the ICU. Chest 1998;113:4928.

12. Macha M, Molina EJ, Franco M, Luyun L, Gaughan JP, McClurken $\mathrm{JB}$, et al. Pre-transplant obesity in heart transplantation: are there predictors of worse outcomes? Scand Cardiovasc J 2009;43:304-10.

13. Yang J, Hu J, Zhu C. Obesity aggravates COVID-19: A systematic review and meta-analysis. J Med Virol 2021;93:257-61.

14. Du Y, Lv Y, Zha W, Zhou N, Hong X. Association of body mass index (BMI) with critical COVID-19 and in-hospital mortality: A doseresponse meta-analysis. Metabolism 2021;117:154373.

15. Cai Q, Huang D, Ou P, Yu H, Zhu Z, Xia Z, et al. COVID-19 in a designated infectious diseases hospital outside Hubei Province, China. Allergy 2020;75:1742-52.

16. Kooistra EJ, Brinkman S, van der Voort PHJ, de Keizer NF, Dongelmans DA, Kox M, et al. Body Mass Index and Mortality in Coronavirus Disease 2019 and Other Diseases: A Cohort Study in 35,506 ICU Patients. Crit Care Med 2021 Jul 16.
17. https://covid19.saglik.gov.tr/TR-66301/covid-19-rehberi.html

18. WHO - World Health Organization. Obesity and overweight 2010. Updated June 2016.

19. EASO - European Association for the Study of Obesity: Obesity facts and figures. Available from: URL: http:// easo.org/educationportal/obesity-facts-figures/

20. Andersen CJ, Murphy KE, Fernandez ML. Impact of Obesity and Metabolic Syndrome on Immunity. Adv Nutr 2016;7:66-75.

21. Lighter J, Phillips M, Hochman S, Sterling S, Johnson D, Francois F, et al. Obesity in Patients Younger Than 60 Years Is a Risk Factor for COVID-19 Hospital Admission. Clin Infect Dis 2020;71:896-7.

22. Huang R, Zhu L, Xue L, Liu L, Yan X, Wang J, et al. Clinical findings of patients with coronavirus disease 2019 in Jiangsu province, China: A retrospective, multi-center study. PLoS Negl Trop Dis 2020;14:e0008280.

23. Sabaz MS, Özdemir F, Özakin O, Türkmen ÜA, Dinç V. Intensive Care Unit Admission Parameters for Patients with COVID-19. Med J Bakirkoy 2021;17:254-61.

24. Erol AT, Aşar S, Ören Bilgin B, Çukurova Z, Sabaz MS. Risk Factors for 28-day Mortality Among COVID-19 Patients in an Intensive Care Unit of a Tertiary Care Center in Istanbul. Med J Bakirkoy 2021;17:100-7.

25. Imam Z, Odish F, Gill I, O'Connor D, Armstrong J, Vanood A, et al. Older age and comorbidity are independent mortality predictors in a large cohort of 1305 COVID-19 patients in Michigan, United States. J Intern Med 2020;288:469-76.

26. Sabaz MS, Aşar S. Association of Charlson Comorbidity and Pneumonia Severity Indices with Mortality in Patients with Coronavirus Disease-2019 in the Intensive Care Unit. Turk J Intensive Care 2021;19:33-41.

27. Tuty Kuswardhani RA, Henrina J, Pranata R, Anthonius Lim M, Lawrensia S, Suastika K. Charlson comorbidity index and a composite of poor outcomes in COVID-19 patients: A systematic review and meta-analysis. Diabetes Metab Syndr 2020;14:2103-9.

28. Chiappetta S, Sharma AM, Bottino V, Stier C. COVID-19 and the role of chronic inflammation in patients with obesity. Int J Obes (Lond) 2020;44:1790-2.

29. Heinonen S, Saarinen L, Naukkarinen J, Rodríguez A, Frühbeck G, Hakkarainen A, et al. Adipocyte morphology and implications for metabolic derangements in acquired obesity. Int J Obes (Lond) 2014;38:1423-31.

30. Leal Vde O, Mafra D. Adipokines in obesity. Clin Chim Acta 2013;419:87-94.

31. Koenig SM. Pulmonary complications of obesity. Am J Med Sci 2001;321:249-79.

32. Pépin JL, Borel JC, Janssens JP. Obesity hypoventilation syndrome: an underdiagnosed and undertreated condition. Am J Respir Crit Care Med 2012;186:1205-7.

33. Chlif M, Keochkerian D, Choquet D, Vaidie A, Ahmaidi S. Effects of obesity on breathing pattern, ventilatory neural drive and mechanics. Respir Physiol Neurobiol 2009;168:198-202.

34. Salome CM, King GG, Berend N. Physiology of obesity and effects on lung function. J Appl Physiol (1985) 2010;108:206-11.

35. Kim IB, Prowle J, Baldwin I, Bellomo R. Incidence, risk factors and outcome associations of intra-abdominal hypertension in critically ill patients. Anaesth Intensive Care 2012;40:79-89.

36. Aşar S, Kucur Tülübaş E, Sabaz MS, Acicbe Ö. The Effect of PEEP Adjusted by Automatic Recruitment Maneuver on Total and Dynamic Mechanical Power in Bariatric Surgery. Med J Bakirkoy 2021;17:262-7. 
37. Gong MN, Bajwa EK, Thompson BT, Christiani DC. Body mass index is associated with the development of acute respiratory distress syndrome. Thorax 2010;65:44-50.

38. Asar S, Acicbe Ö, Sabaz MS, Tontu F, Canan E, Cukurova Z, et al. Comparison of Respiratory and Hemodynamic Parameters of COVID-19 and Non-COVID-19 ARDS Patients. Indian J Crit Care Med 2021;25:704-8.

39. Sabaz MS, Așar S. Identification of Factors Associated with Prolonged Stay in the Intensive Care Unit. Med J Bakirkoy 2021;17:233-42.

40. Kass DA, Duggal P, Cingolani O. Obesity could shift severe COVID-19 disease to younger ages. Lancet 2020;395:1544-15.

41. Gao F, Zheng KI, Wang XB, Sun QF, Pan KH, Wang TY, et al. Obesity Is a Risk Factor for Greater COVID-19 Severity. Diabetes Care 2020;43:e72-4.

42. Dolgun E, Yavuz M. Aşııı şişmanlık cerrahisinde hemşirelik bakımı. (Nursing Care in Morbid Obesity Surgery). Maltepe Üniversitesi Hemşirelik Bilim ve Sanatı Dergisi 2010;3:85-92.

43. Terekeci H, Kucukardali Y, Top C, Onem Y, Celik S, Oktenli C. Risk assessment study of the pressure ulcers in intensive care unit patients. Eur J Intern Med 2009;20:394-7.

44. Sabaz MS, Aşar S, Sertçakacılar G, Sabaz N, Çukurova Z, Hergünsel $\mathrm{GO}$. The effect of body mass index on the development of acute kidney injury and mortality in intensive care unit: is obesity paradox valid? Ren Fail 2021;43:543-55.

45. Hergünsel GO, Sabaz MS. The effect of obesıty on mortalıty in geriatrıc patıents followed in the intensıve care unit. Turkish Journal of Geriatrics 2021;24:315-29.

46. Sabaz MS, Çetingök H, Sertcakacilar G, Yener YZ, Atiç E, Erbahceci Salik A, et al. Monitorization of NGAL, Creatinine and Renal Blood Flow in the Follow-up of Acute Kidney Injury in Intensive Care. Med J Bakirkoy 2021;17:85-93.

47. Winkelman C, Maloney B, Kloos J. The impact of obesity on critical care resource use and outcomes. Crit Care Nurs Clin North Am 2009;21:403-22.

48. Frank RC, Mendez SR, Stevenson EK, Guseh JS, Chung M, Silverman MG. Obesity and the Risk of Intubation or Death in Patients With Coronavirus Disease 2019. Crit Care Med 2020;48:e1097-101.

49. Tartof SY, Qian L, Hong V, Wei R, Nadjafi RF, Fischer $H$, et al. Obesity and Mortality Among Patients Diagnosed With COVID-19: Results From an Integrated Health Care Organization. Ann Intern Med 2020;173:773-81.

50. Wolf M, Alladina J, Navarrete-Welton A, Shoults B, Brait K, Ziehr $D$, et al. Obesity and Critical Illness in COVID-19: Respiratory Pathophysiology. Obesity (Silver Spring) 2021;29:870-8. 